\title{
STABILITY-INDICATING HIGH-PERFORMANCE LIQUID CHROMATOGRAPHY METHOD FOR DETERMINATION OF ANTIHISTAMINE DRUG AZELASTINE
}

\author{
SHITAL PATEL*, PASHA TY \\ Department ofPharmaceutical Analysis, Parul Institute of Pharmacy, Ta.-Waghodia, Vadodara - 391 760, Gujarat, India. \\ Email: shital_3012@yahoo.com
}

Received: 27 February 2018, Revised and Accepted: 01 May 2018

\section{ABSTRACT}

Objective: The objective of this research was to develop a simple, precise, accurate, and stability-indicating reverse-phase high-performance liquid chromatographic method for estimation of azelastine hydrochloride (AZL) in nasal spray preparation.

Methods: Chromatography was performed on a $250 \mathrm{~mm} \times 4.6 \mathrm{~mm}, 5-\mu \mathrm{m}$ particle size, Waters Spherisorb CN column using (50:50 v/v) mixture of potassium dihydrogen phosphate buffer and acetonitrile as mobile phase. The detection was carried out at $290 \mathrm{~nm}$ and flow rate employed was $1.0 \mathrm{ml} / \mathrm{min}$. The degradation of AZL was studied under different ICH recommended stress conditions.

Results: The retention time was $4.34 \mathrm{~min}$ for AZL. Linearity was established in the concentration range of $5-120 \mu \mathrm{g} / \mathrm{ml}$, with a correlation coefficient of 0.9996 . Limit of detection (LOD) and limit of quantitation (LOQ) were found to be $0.81 \mu \mathrm{g} / \mathrm{ml}$ and $2.44 \mu \mathrm{g} / \mathrm{ml}$, respectively. Percentage recovery was found between 99 and $102 \%$. The values of percentage relative standard deviation $(<2 \%)$ proved the high precision of the proposed method. The method was found to be robust regarding any small variation in the column temperature, $\mathrm{pH}$ of mobile phase, and mobile phase ratio. AZL was found stable in $5 \mathrm{M} \mathrm{HCl}$ at $80^{\circ} \mathrm{C}$ for $5 \mathrm{~h}, 5 \mathrm{M} \mathrm{NaOH}$ at $80^{\circ} \mathrm{C}$ for $5 \mathrm{~h}, 30 \% \mathrm{H}_{2} \mathrm{O}_{2}$ at $80^{\circ} \mathrm{C}$ for $5 \mathrm{~h}$, and in oven at $70^{\circ} \mathrm{C}$ for $8 \mathrm{~h}$.

Conclusion: The results obtained in this research work clearly proved that the proposed HPLC method for the assay of AZL in nasal spray preparation is simple, precise, specific, accurate, and stability indicating. It indicates that the method is suitable for analysis of AZL in the raw material and the pharmaceutical product without interference from excipients.

Keywords: Azelastine hydrochloride, High-performance liquid chromatography, Degradation study, Stability-indicating method.

(C) 2018 The Authors. Published by Innovare Academic Sciences Pvt Ltd. This is an open access article under the CC BY license (http://creativecommons. org/licenses/by/4. 0/) DOI: http://dx.doi.org/10.22159/ajpcr.2018.v11i8.25506

\section{INTRODUCTION}

Allergic reaction produces inflammation, and people, who suffer from nasal allergies such as hay fever, dust, mite, and pet allergies, tend to experience a variety of symptoms due to this inflammation. Inflammation of the nasal passage forces fluid out of the nasal tissues, resulting in a runny and blocked nose. The three main types of drugs available for anti-inflammatory and antiallergic effect are corticosteroids, antihistamines, and decongestants [1].

Azelastine hydrochloride (AZL), which is a second-generation $\mathrm{H}_{1}$ receptor antagonist, chemically, it is known as 4-[(4-Chlorophenyl) methyl]-2-(hexahydro-1-methyl-1 H-azepin-4-yl)-1(2H)phthalazinone, hydrochloride. The chemical structure of AZL is shown in Fig. 1. AZL occurs as a white, almost odorless, crystalline powder with a bitter taste. It has a molecular weight of 418.37. It also inhibits lipoxygenase and platelet aggregation. It is bronchodilator agent also. It is indicated as antiallergic agent $[2,3]$.

AZL is an official drug in British Pharmacopoeia [2], which recommends a titrimetric method for the determination of AZL in pure form using $0.1 \mathrm{M}$ perchloric acid as a titrant. Various methods such as liquid chromatography (LC) [4], LC-electrospray ionization tandem mass spectrometry [5], high-performance LC (HPLC) [6,7], capillary HPLC [8], and electrokinetic capillary HPLC [8] had been reported for the determination of azelastine and its metabolite in biofluids. Visible spectrophotometric method [9], HP thin-layer chromatography (HPTLC) [10], reversed-phase HPLC (RP-HPLC) [11], and Fourier transform infrared [12] have been developed for estimation of AZL in formulation. RP-HPLC [13] method has been reported for simultaneous estimation of AZL and fluticasone propionate in formulation. Salama et al. [14] have established stability-indicating densitometry TLC method for quantitative determination of azelastine $\mathrm{HCl}$ in the presence of their acid and oxidative degradants produced by refluxing drug in $5 \mathrm{M}$ $\mathrm{HCl}$ for $36 \mathrm{~h}$ and $30 \% \mathrm{H}_{2} \mathrm{O}_{2}$ for $30 \mathrm{~h}$, respectively. In the study performed by Rao et al. [13], the forced degradation was done by refluxing drug into individual flasks at $60^{\circ} \mathrm{C}$ for $1 / 2 \mathrm{~h}$ with $0.1 \mathrm{~N} \mathrm{HCl}, 0.1 \mathrm{~N} \mathrm{NaOH}, 1.0 \%$ $\mathrm{H}_{2} \mathrm{O}_{2}$, and water. None of the methods satisfy the stability protocol as per regulatory guidance. An ideal stability-indicating method is one which quantifies the drug and resolves it from its degradation products. These facts initiate the present study to establish an accurate, specific, repeatable, and stability-indicating HPLC method for analysis of AZL in the presence of its degradation products. The suggested method was designed to be suitable for routine analysis of the drug in pharmaceutical formulations. The proposed method was validated in accordance with ICH guidelines $[15,16]$.

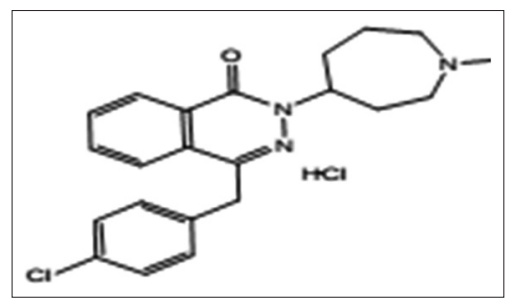

Fig. 1: Chemical structure of azelastine hydrochloride 


\section{METHODS}

\section{Instrumentation and chromatographic condition}

The quantitative analysis was performed on Agilent HPLC 1260 equipped with quaternary solvent manager, autosampler, and photodiode array (PDA) detector integrated with Ez chrome software. Separation was achieved on Waters Spherisorb CN $(250 \times 4.6 \mathrm{~mm}, 5 \mu \mathrm{m})$ column. The standards and samples were separated using mobile phase consisting of acetonitrile:0.05 M potassium dihydrogen phosphate buffer $\mathrm{pH} 3.0(50: 50 \% \mathrm{v} / \mathrm{v})$. The flow rate was $1.0 \mathrm{ml} / \mathrm{min}$ and detection was set at $290 \mathrm{~nm}$. The column temperature was set at $45^{\circ} \mathrm{C}$, and the injection volume was $20 \mu$ l.

\section{Materials and reagents}

AZL (certified purity of $99.8 \%$, batch no. 0301425316) was kindly gifted by Cadila Health Care Limited, Moraiya (Gujarat). Arzep nasal solution was purchased from local pharmacy. Acetonitrile and water (HPLC grade) were purchased from Merck, India. Potassium dihydrogen phosphate, 0-phosphoric acid (OPA), sodium hydroxide, hydrochloric acid, and hydrogen peroxide used were of analytical grade and purchased from S.D. Fine Chemicals, India.

\section{Standard stock solution preparation}

A standard solution of AZL containing $1000 \mu \mathrm{g} / \mathrm{ml}$ was prepared in acetonitrile and diluted as appropriate with the same solvent to obtain the working concentration range. Solutions were found to be stable for at least 5 days when kept at room temperature.

\section{Buffer preparation (pH 3.0)}

About $6.805 \mathrm{~g}$ of potassium dihydrogen phosphate was dissolved in $600 \mathrm{ml} \mathrm{HPLC}$ water and then final volume was made up to $1000 \mathrm{ml}$ with HPLC water. Buffer $\mathrm{pH}$ was adjusted to 3.0 with ortho-OPA.

\section{Validation of the method}

The method was validated for system suitability, specificity, linearity, precision, accuracy, limit of detection (LOD), limit of quantification (LOQ), and robustness as per the ICH guideline.

\section{System suitability}

The system suitability was checked by seven replicate analyses of $100 \mu \mathrm{g} / \mathrm{ml}$ solution of AZL and chromatographic parameters were evaluated.

\section{Linearity}

Accurately measured volumes of the AZL standard solution were successively transferred into a series of $10 \mathrm{ml}$ volumetric flasks to obtain final concentrations of $5-120 \mu \mathrm{g} / \mathrm{ml}$ and diluted to the mark with acetonitrile and solutions were mixed properly. $20 \mu$ aliquots of each solution were injected 3 times and were chromatographed. The average peak area of AZL was plotted against the drug concentration, and the regression equation was derived.

\section{Precision}

Repeatability of the method was assessed by analysis of seven injections of $100 \mu \mathrm{g} / \mathrm{ml}$ AZL solution. Percentage relative standard deviation (\%RSD) for retention time and peak area of drug was calculated. The intraday and interday precision for analysis of AZL was performed with three concentrations $(20,40$, and $60 \mu \mathrm{g} / \mathrm{ml})$ for 3 times on the same day and for three different days, respectively.

\section{Specificity - forced degradation studies}

The forced degradation study was executed to find whether the analytical method was stability indicating and could determine the AZL in the presence of impurities and degradation products. AZL standard solution was stressed under acid, base, oxidative, thermal, and photolytic stress conditions. $2 \mathrm{ml}$ of the standard solution of AZL $(1000 \mu \mathrm{g} / \mathrm{ml})$ was transferred to three $20 \mathrm{ml}$ volumetric flask followed by $2 \mathrm{ml}$ of $5.0 \mathrm{M} \mathrm{HCl}, 2 \mathrm{ml}$ of $5.0 \mathrm{M} \mathrm{NaOH}$, and $2 \mathrm{ml}$ of $30 \% \mathrm{H}_{2} \mathrm{O}_{2}$ to different flask and then heated in a thermostatic water bath at $80^{\circ} \mathrm{C}$ for $5 \mathrm{~h}$ to induce degradation by acid, base, and oxidation, respectively. Then, the mixtures were diluted with acetonitrile up to the mark. $50 \mathrm{mg}$ AZL powder was placed in convection oven and exposed to heat at $70^{\circ} \mathrm{C}$ for $8 \mathrm{~h}$ and further preceded as per sample preparation for thermal degradation. To check photolytic degradation, AZL drug (50 mg) was taken in two Petri dishes. One Petri dish was wrapped with aluminum foil and other was not wrapped. Both the Petri dishes were kept in ultraviolet chamber $(365 \mathrm{~nm})$ for $24 \mathrm{~h}$ at room temperature and further preceded as per sample preparation. The photostability of a drug substance depends on the wavelength, time, and intensity of exposure [17]. All stressed samples were analyzed by proposed method.

\section{Accuracy}

Accurately measured $2 \mathrm{ml}$ of nasal spray equivalent to $20 \mathrm{mg}$ of AZL was taken in three different $10 \mathrm{ml}$ volumetric flasks. $10 \mathrm{mg}, 20 \mathrm{mg}$, and $30 \mathrm{mg}$ of AZL standard was added to three different volumetric flasks containing nasal spray preparation and diluted up to mark with acetonitrile. Further, they were diluted to have $40 \mu \mathrm{g} / \mathrm{ml}$ of sample in each flask. The experiment was performed in triplicate. Percentage recovery was calculated for each level.

\section{Robustness}

To determine the robustness of the method, the experimental conditions were deliberately changed. The flow rate of the mobile phase $(1.0 \pm 0.1 \mathrm{ml} / \mathrm{min}), \mathrm{pH}$ of mobile phase $(3.0 \pm 0.2)$, mobile phase composition $( \pm 2 \%)$, and column temperature $\left(45 \pm 1^{\circ} \mathrm{C}\right)$ was varied. In each case, the \%RSD values were calculated for the obtained retention time and peak area. The number of theoretical plates and tailing factor was compared with that obtained under the optimized conditions.

\section{LOD and LOQ}

The LOD and LOQ were estimated mathematically. The mathematical formulas used were as follows:

- $\quad \mathrm{LOD}=3.3$ (SD of y-intercept/slope of the calibration plot)

- $\mathrm{LOQ}=10$ (SD of $\mathrm{y}$-intercept/slope of the calibration plot).

\section{Analysis of the marketed formulation}

To determine the AZL content of a nasal spray (label claim $1 \% \mathrm{w} / \mathrm{v}, 10 \mathrm{ml}$ ), solution of the container was taken out in $100 \mathrm{ml}$ volumetric flask and mixed with acetonitrile $(10 \mathrm{ml})$ and sonicated for $20 \mathrm{~min}$, then it was diluted up to the mark with acetonitrile which made $1 \mathrm{mg} / \mathrm{ml}$ AZL concentration. $1 \mathrm{ml}$ of this solution was transferred to a $10 \mathrm{ml}$ volumetric flask and diluted to volume with acetonitrile which made $100 \mu \mathrm{g} / \mathrm{ml}$. The analysis was repeated 3 times. The possibility of interference of excipients with the analysis was studied.

\section{RESULTS}

\section{Development of method}

To develop stability-indicating HPLC method for antihistamine drug AZL, mobile phases of various compositions were investigated and system suitability test was performed for method optimization. The mobile phase consisting of acetonitrile: $0.05 \mathrm{M}$ potassium dihydrogen phosphate buffer $\mathrm{pH} 3.0(50: 50 \% \mathrm{v} / \mathrm{v})$ was found to furnish sharp and well-defined peak with very good symmetry (1.43), theoretical plates $(>10,000)$, and low retention time (Fig. 2). Other tried mobile phases gave too broad peak or asymmetric peak, so were not considered. A wavelength maximum of the AZL is $215 \mathrm{~nm}$ but to avoid interference from solvent $290 \mathrm{~nm}$ was chosen for detection of eluents. The $\mathrm{pH}$ of mobile phase was studied from 3.0 to 7.0. At higher pH, AZL peak lost the sharpness and precision of the retention time. Finally, the mobile phase of $\mathrm{pH} 3.0$ was chosen as optimum. The ratio of acetonitrile and buffer was also studied. The mobile phase consisting of $50 \%$ acetonitrile was found optimum. The effect of flow rate was also optimized and $1.0 \mathrm{ml} / \mathrm{min}$ was considered optimum for the separation method. The column temperature was set at $45^{\circ} \mathrm{C}$. 
Validation of method

The proposed method was validated according to the ICH guideline to prove its suitability for the intended purpose. Method validation data are summarized in Table 1.

\section{Linearity}

Peak area and concentration were subjected to linear regression analysis to calculate the calibration equation and correlation coefficient (Fig. 3). The regression data revealed a good linear relationship over the concentration range of $5-120 \mu \mathrm{g} / \mathrm{ml}$.

\section{Precision}

The precision of an analytical method gives information on random error. The precision of the method was evaluated by repeatability, interday and intraday precision. The values of \%RSD for all found $<2 \%$ proved the high precision of the proposed method.

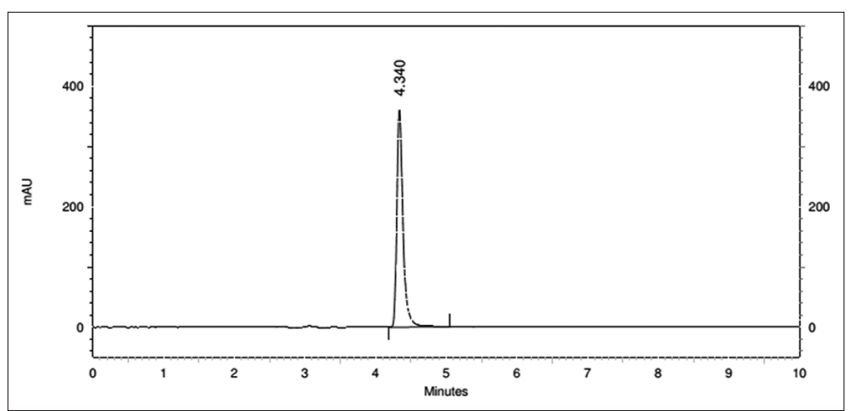

Fig. 2: Chromatogram of AZL standard $(100 \mu \mathrm{g} / \mathrm{ml})$

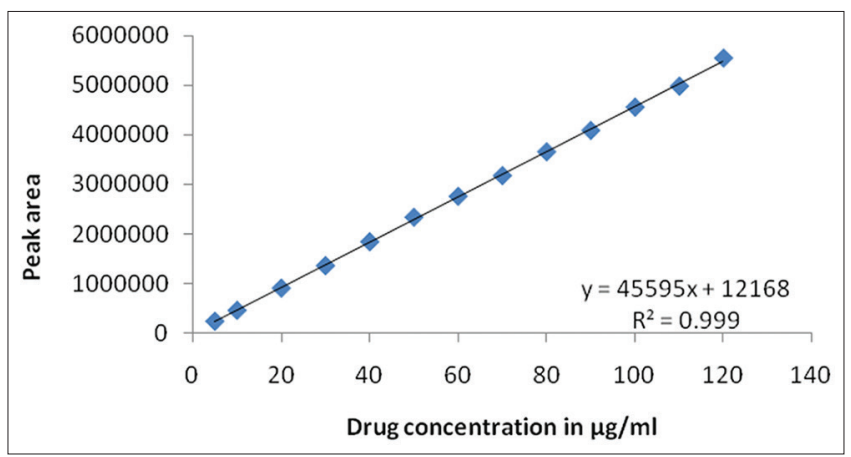

Fig. 3: Linearity curve

Table 1: Validation data

\begin{tabular}{ll}
\hline Data & Value \\
\hline Linear range & $5-120 \mu \mathrm{g} / \mathrm{ml}$ \\
Correlation coefficient $\left(\mathrm{r}^{2} \pm \mathrm{SD}^{\mathrm{a}}\right)$ & $0.9996 \pm 0.0002$ \\
LOD & $0.81 \mu \mathrm{g} / \mathrm{ml}$ \\
LOQ & $2.44 \mu \mathrm{g} / \mathrm{ml}$ \\
Accuracy & $100.05 \pm 0.95$ \\
Precision $\left(\% \mathrm{RSD}^{\mathrm{b}}\right)$ & \\
Repeatability $(\mathrm{n}=7)$ & 1.381 \\
Interday $(\mathrm{n}=3)$ & 0.800 \\
Intraday $(\mathrm{n}=3)$ & 0.372 \\
Robustness & Robust in column temperature, \\
& pH of mobile phase $(3.0 \pm 0.1)$, \\
& and mobile phase composition \\
Specificity & Specific \\
\hline
\end{tabular}

Note: ${ }^{\mathrm{a}}=$ standard deviation, ${ }^{\mathrm{b}}=$ relative standard deviation. LOD: Limit of detection, LOQ: Limit of quantitation, \%RSD: Percentage relative standard deviation

\section{Accuracy}

When the method was used for subsequent analysis of AZL from the nasal spray solution after spiking of AZL standard at three different levels for 3 times, the recovery was found between 99 and $102 \%$ (Table 2). The percentage recovery was calculated from the amount recovered and actual amount added. Amount recovered was calculated from comparison of area before and after spiking the standard drug.

\section{LOD and LOQ}

LOD and LOQ were found to be $0.81 \mu \mathrm{g} / \mathrm{ml}$ and $2.44 \mu \mathrm{g} / \mathrm{ml}$, respectively, from calculation.

\section{Robustness}

The method was found to be robust regarding any small variation in the column temperature $\left(45 \pm 1^{\circ} \mathrm{C}\right), \mathrm{pH}$ of mobile phase $(3.0 \pm 0.2)$, and mobile phase composition $( \pm 2 \%)$ as revealed by the constancy of the retention time and the peak area. In case of flow rate of mobile phase $(1 \pm 0.1 \mathrm{ml} / \mathrm{min})$, where minor variation resulted in a significant change in the retention and peak area of the AZL.

\section{Stability-indicating aspects}

Any significant change in peak area of AZL and any additional peak were not observed when chromatographed after refluxing with $5.0 \mathrm{M} \mathrm{HCl}$, $5.0 \mathrm{M} \mathrm{NaOH}$, and $30 \% \mathrm{H}_{2} \mathrm{O}_{2}$ for $5 \mathrm{~h}$ in separate flasks. No additional peak was observed and no significant change in initial concentration of AZL when solid AZL drug kept at $365 \mathrm{~nm}$ for $24 \mathrm{~h}$. AZL samples kept under dry heat conditions furnished no additional peaks. Peak purity value of AZL was found 1.00 after exposure to forced degradation condition. Hence, AZL is stable under acid, alkali, oxidative, dry heat, and $365 \mathrm{~nm}$ for $24 \mathrm{~h}$ photolytic condition.

\section{Assay of the pharmaceutical formulation}

The proposed validated method was successfully applied to determine AZL in Arzep nasal spray solution. The recovery obtained was around $96.14 \%$. In chromatograms of drug sample from nasal spray preparation, no interference was observed from excipients.

\section{DISCUSSION}

The present study was aimed at developing a precise, specific, robust, and accurate HPLC method for the analysis of AZL in bulk drug and in pharmaceutical dosage form. The author developed stabilityindicating HPLC method and validated for the determination of AZL in bulk and nasal spray solution using Waters Spherisorb CN column $(250 \mathrm{~mm} \times 4.6 \mathrm{~mm}, 5 \mu \mathrm{m})$. The mobile phase consists of potassium dihydrogen phosphate buffer $(\mathrm{pH} 3.0)$ :acetonitrile (40:50 v/v) was used throughout the analysis. The flow rate was $1.0 \mathrm{ml} / \mathrm{min}$, the injection volume was $20 \mu \mathrm{l}$, column temperature was $45^{\circ} \mathrm{C}$, run time $6 \mathrm{~min}$, and detection was performed at $290 \mathrm{~nm}$ using a PDA detector. The retention time of AZL was found to be $4.34 \mathrm{~min}$. The linearity was found satisfactory in the range of $5-120 \mu \mathrm{g} / \mathrm{ml}$ and showed good correlation coefficient values 0.9996 . Less \%RSD values showed good precision of the method. The results obtained by the forced degradation studies were enough to say that the drug is stable and method is stability indicating one. The comparison of the developed method with published methods shows the developed method is simple, robust, and economical one.

Table 2: Results of accuracy for AZL

\begin{tabular}{llll}
\hline $\begin{array}{l}\boldsymbol{\%} \\
\text { Addition }\end{array}$ & $\begin{array}{l}\boldsymbol{\mu g} / \mathbf{m l} \\
\text { added }\end{array}$ & $\begin{array}{l}\boldsymbol{\mu g} / \mathbf{m l} \\
\text { recovered }\end{array}$ & $\begin{array}{l}\% \\
\text { recovery } \pm \text { SD }(\mathbf{n}=3)\end{array}$ \\
\hline 50 & 20 & 19.91 & $99.54 \pm 1.29$ \\
100 & 40 & 40.46 & $101.14 \pm 0.70$ \\
150 & 60 & 59.67 & $99.46 \pm 0.72$ \\
\hline
\end{tabular}

AZL: Azelastine hydrochloride 


\section{CONCLUSION}

The proposed HPLC method for the assay of AZL in nasal spray preparation is simple, precise, specific, accurate, and stability indicating. It proves that the method is suitable for analysis of AZL in the raw material and the pharmaceutical product without interference from excipients. A stress degradation study was conducted to investigate the degradation behavior of AZL under ICH recommended condition; it shows that AZL is stable drug.

\section{ACKNOWLEDGMENT}

The authors would like to thank Cadila Health Care Limited, Moraiya, Gujarat, for providing AZL as gift sample for this research work.

\section{AUTHOR'S CONTRIBUTION}

Shital Patel has performed the work presented here. Dr. T. Y. Pasha has guided this project.

\section{CONFLICTS OF INTEREST}

All authors have none to declare.

\section{REFERENCES}

1. Chudiwal SS, Dehghan MH. A study of method development and validation for estimation of flunisolide in nasal spray formulations by RP-HPLC method. Int J Pharm Pharm Sci 2016;8:141-6.

2. HMSO Publication. British Pharmacopoeia. Vol. 1. London: HMSO Publication; 2009. p. 488-91.

3. Krishnan PV. Current Index of Medical Specialities (CIMS). Vol. 116. Banglore: Bio Grad Medical Services; 2012.

4. Pivonka J, Segelman FH, Hartman CA, Segl WE, Kucharezyk N, Sofia RD. Determination of azelastine and desmethylazelastine in human plasma by high performance liquid chromatography. J Chromatography B Biomed Sci Appl 1987;420:89-98.

5. Park YS, Kim SH, Kim YJ, Yang SC, Lee MH, Shaw LM, et al. Determination of azelastine in human plasma by validated liquid chromatography coupled to tandem mass spectrometry(LC-ESI/MS/MS) for the clinical studies. Int J Biomed Sci 2010;6:120-7.

6. Langevin CN, Pivonka J, Wichmann JK, Kucharczyk N, Sofia RD.
High performance liquid chromatographic determination of azelastine and desmethylazelastine in guinea pig plasma and lung tissue. Biomed Chromato 1993;7:7-11

7. Zha W, Shum L. Simultaneous determination of azelastine and its major metabolite desmethylazelastine in human plasma using high performance liquid chromatography-tandem mass spectrometry. J Chromato B 2012;906:69-74.

8. Heinemann U, Blaschke G, Knebel N. Simultaneous enantio selective separation of azelastine and three of its metabolites for the investigation of the enantiomeric metabolism in rats: I. Liquid chromatographyionspray tandem mass spectrometry and electrokinetic capillary chromatography. J Chromato B 2003;793:389-404.

9. Salama NN, Abdel-Razeq SA, Atty SA, Kosy NE. Spectrophotometric determination and thermodynamic studies of the charge transfer complexes azelastine hydrochloride. Bull Fac Pharm Cario Univ 2011;49:13-8.

10. Wyszomirska E, Czerwinska K, Kublin E, Mazurek AP. Identification and determination of ketotifen hydrogen fumarate, azelastine hydrochloride, dimetindene maleate and promethazine hydrochloride by densitometric method. Acta Pol Pharmaceut 2013;70:951-9.

11. Boovizhikannan T, Palanirajan VK. RP-HPLC determination of azelastine in pure and in ophthalmic formulation. Int J Pharm Sci Rev Res 2012;17:62-4.

12. Patel RB, Patel NK. Development and validation of IR spectrophotometric method for estimation of azelastine hydrochloride in nasal spray preparations. Available from: http://www.pharmatutor. org/articles/development-validation-ir-spectrophotometric-methodestimation-azelastine-hydrochloride-nasalspray-preparations.

13. Rao KL, Reddy KP, Babu KS, Raju KS, Rao KV, Sharik JV. Simultaneous estimation of fluticasone propionate, azelastine hydrochloride, phenylethyl alcohol and benzalkonium chloride by rp-hplc method in nasal spray preparations. Int J Res Pharm Sci 2010;1:473-80.

14. Salama NN, Abdel-Razeq SA, Atty SA, Kosy NE. Development and validation of densitometry tlc stability indicating method for quantitative determination of azelastine hydrochloride and emedastine difumarate in their drug products. Br J Pharm Res 2014;4:79-92.

15. ICH Harmonised Tripartite Guideline Test on Validation of Analytical Procedures Q2A; 1994.

16. ICH Harmonised Tripartite Guideline Validation of Analytical Procedure: Methodology (Q2B); 1996.

17. Gul W. Photostability testing of formulated phaemaceutical products. Int J Pharm Pharm Sci 2015;2:65-8. 